\title{
AFTER THE NEW PERSPECTIVE: WORKS, JUSTIFICATION AND BOASTING IN EARLY JUDAISM AND ROMANS $1-5^{1}$
}

\section{Simon Gathercole}

Whatever justification could there be for another thesis on Paul's relationship to Judaism? One aspect of this relationship which has slipped through the net and failed to receive adequate treatment in recent scholarship is that of 'boasting'. Apart from a handful of short articles (e.g. by C.H. Dodd 1933, R. Bultmann 1965, and C.K. Barrett 1986) there has been no full-scale treatment of this theme in Romans, despite commentators' frequent acknowledgement of its importance. The only major discussion, J.S. Bosch's Gloriarse según san Pablo, was written in 1970, and so takes no account of the recent paradigm shift in Pauline studies. Its second disadvantage is being written in Spanish, and so not having found a wide readership.

There is, however, a problem surrounding what is perhaps at first sight a moderately unproblematic concept. Probing beneath the surface of Romans $1-5$, as well as the commentaries and other secondary literature, it becomes apparent that the discussion of 'boasting' cuts right to the heart of the debate between traditional and 'New Perspective' interpretations of Paul's relationship to his Jewish contemporaries. Is boasting, as in the traditional position, 'the human tendency to rely on one's own powers and to think that thereby one can achieve salvation or justification in the sight of God' (J.A. Fitzmyer)? Or is it rather that 'the boast of the Jew is directed not to their own fulfilment of the Law, but to the possession of the Torah as the revelation of God' (U. Wilckens), and thus that election alone is determinative for salvation, in the Jewish mindset? The former was emphasised in particular by the Reformers, and has also been argued by such towering figures as R. Bultmann, E. Käsemann, and C.E.B. Cranfield; the latter is advanced equally forcefully by E.P. Sanders, J.D.G. Dunn, R.B. Hays, and N.T. Wright.

1 S.J. Gathercole, After the New Perspective: Works, Justification and Boasting in Early Judaism and Romans 1-5 (Ph.D. Thesis, University of Durham, 2001); Supervisor: Prof. James D.G. Dunn. 
Thus problems defining 'boasting' cannot be resolved by widerranging word-study; nor is 'boasting' just another under-researched idea: how Paul's relationship to his Jewish contemporaries is seen is at stake. This in turn impacts the Christian doctrine of justification.

In short, to understand Second-Temple Judaism as 'covenantal nomism' downplays, ignores, or denies the role of obedience as a decisive criterion for final vindication in the Jewish texts. This in turn leads to misconstrual of key texts such as 'no one will be justified by works of the Law' (3:20). Such texts refer-so Sanders, Dunn, and Wright-to Paul's critique of the attitude that those marked out by circumcision, Sabbath, and the food-laws are those who will be confirmed as God's people. Against this, it is argued that Paul actually focuses in 3:20 on the inability of the flesh (cf. 8:3) to obey Torah and thereby to be justified.

The first half of this thesis (Chapter 1) argues in detail that alongside the emphasis on God's gracious election in Second-Temple Jewish literature (argued for powerfully by Sanders), there is nevertheless a firm belief in final vindication on the basis of works. Obedience leads to final justification. This cannot be branded with blanket terms like 'legalism', or 'works-righteousness'; it is necessary to develop analytical terms and tools that can examine the texts with greater sensitivity. On the other hand, it is necessary to acknowledge that there are numerous references to final salvation as 'repayment', 'reward' (e.g. of eternal life, or of participation in rule in God's Kingdom), or as 'prize' for winning a contest. Most importantly in the current climate of NT studies, such models of final salvation are found not just in diaspora texts or texts from after the destruction of the Temple, but also from early Palestinian literature such as Psalms of Solomon, the Qumran literature, and Pseudo-Philo. Numerous other texts, however, from the diaspora and the period immediately post-70 $\mathrm{AD}$ do confirm a very similar pattern.

Chapter 2 argues that, beside general soteriological statements, there are specific Jewish articulations of confidence that God will vindicate his people on the basis not only of his mercy, but also on that of their obedience. Such statements appear in a variety of texts (not just later/non-Palestinian ones, but also Baruch, Assumption of Moses, and CD) and are put into the mouths of all Israel/specific groups within Israel/certain individuals, contradicting New Perspective interpretations of Judaism which ignore such statements.

Three chapters follow offering an exegesis of the key passages in Romans, 2:1-3:20, 3:20-4.8, and 5:1-11, respectively. Exegesis of 
Romans 2 (in thesis Chapter 3) shows in particular that Paul's Jewish interlocutor does not hold to an antinomian position whereby his election guarantees eternal life, irrespective of his sin. Rather, Paul is attempting to convince his interlocutor (who represents the whole nation) that Israel is sinful, as is obvious from both public scandal (2:21-24) and scriptural testimony (3:10-18). Paul's energy in arguing for Israel's sinfulness here shows that his interlocutor was not sufficiently convicted of sinfulness: the Jewish articulations of confidence analysed in the previous chapter can thus reasonably be applied to the Jew of Romans 2. Instead of being righteous, and destined for vindication at the eschaton, the nation is in fact stiffnecked and unrepentant (2:5) and heading for condemnation (2:27; cf. 2:5). Thus Paul's statement in 3:20 does not refer to the inadequacy of works of the Law as boundary-markers of God's people, but rather is a denial of the widespread Jewish assumption that the nation's obedience to Torah would lead to final vindication by God.

This is further sharpened in the course of Paul's exposition in 3:21-4:8 (discussed in thesis Chapter 4). While traditional understandings of this passage do not always do justice to the historical particularity of the 'boasting' in 3:27 as the boast of Israel (e.g. Cranfield), New Perspective readings of these verses are also deeply flawed. The principal problem lies in the understanding that the revelation of the righteousness of God 'apart from the Law' (3:21) signifies God's acceptance of gentiles. Both linguistic analysis of the term $\chi \omega$ pi $\varsigma$ 'apart from', and proper understanding of Paul's surrounding argument shows that Paul is declaring that both Jew and gentile must receive justification apart from works of the Law, because neither is in possession of such obedience. Paul parallels 'apart from the Law' not with those who are 'within the Law' (3:19) but with 'through faith': he contrasts the ways of receiving the righteousness of God, not who is receiving it. The exclusion of boasting in 3:27 is the exclusion not just of privileged status on Israel's part, but is also a declaration of Israel's inability to obey Torah, rendering invalid any confidence, in the present, of future justification. Thus confidence of future vindication is shown to be at the heart of boasting, whether Jewish or Pauline.

Paul's use of Abraham reinforces the fact that the pattern 'works? justification? boasting' is what Paul is critiquing. The Jewish expository tradition (e.g. in 1 Mac., CD) understood Abraham as having been justified on the basis of obedience to God, and, as such, he had a 'boast'. It is not the definition of the boundaries of God's 
people that are at issue here. This is confirmed with the greatest clarity by the account of David in Romans 4:6-8. Here the one who is 'apart from works' is not a gentile, but an Israelite who has sinned.

The fifth chapter explores Paul's reinterpretation of boasting within a Christ-centred theological framework in Romans 5:1-11.

In conclusion, the two interrelated strands running through this thesis can be summed up as follows. First, the Jewish boast is defined neither as a legalistic, self-centred self-confidence which is negative by definition, nor as a confidence based merely on divine election. Rather, it is a conviction of God's gracious election of Israel, and that the nation (or a particular individual or group within the nation) was fulfilling the Law and would be vindicated at the eschaton on that basis. Thus another element of boasting is that it is not a generalised confidence, but is usually oriented toward God's vindication. It is also, then, not merely a feeling of superiority in relation to gentiles (thus Stendahl), but a confidence that God will act on Israel's behalf. As Wilckens notes, 'boasting' is the assurance of salvation (Heilsgewißheit). Second, this analysis of boasting belongs within a fresh understanding of early Jewish soteriology, in which the importance of obedience to Torah as a basis of final salvation is re-affirmed. This has recently been argued by Avemarie, whose work focuses on Rabbinic literature. ${ }^{2}$ This soteriology is also a feature of the earlier pre-70 literature, however, and thus is directly applicable to the Pauline period. Yet Paul's principal objection is not to the doctrine of judgement according to works per se: according to Romans 2, Paul and his interlocutor agree on this. Rather, the disagreement is over the extent of God's grace. In Jewish thought, obedience was the response to God's grace, and was at best merely aided by God. (The exception to this pattern was the Qumran community, but it is clear that Paul is not in debate with, for example, the theology of the Hodayot.) For Paul, on the other hand, God's grace comes not just at the 'election' stage ('getting in'), but is rather the continual driving force in the Christian life. Christ and the Spirit are seen throughout Paul's letters as empowering the obedient service of both the Church and the individual. Unless this is so, justification would be on the basis of work done by the flesh. This Paul has energetically argued to be an impossibility.

2 F. Avemarie, Tora und Leben: Untersuchungen zur Heilsbedeutung der Tora in der frühen rabbinischen Literatur (TSAJ 55; Tübingen: Mohr, 1996). 